\title{
PELATIHAN MANAJEMEN USAHA DAN PENINGKATAN PROMOSI UNTUK PENGEMBANGAN UMKM MAKANAN RINGAN
}

\author{
Ezizwita $^{1)}$, Masruri ${ }^{2)}$, Mellyna Eka Yan Fitri ${ }^{3)}$, Tri Sukma ${ }^{4)}$ \\ ${ }^{1)}$ FEB-Universitas Dharma Andalas Padang \\ ezizwitawita@gmail.com
}

\begin{abstract}
Abstrak
Pengabdian ini dilakukan di Nagari Kamang Hilir, Kecamatan Kamang Magek, Kabupaten Agam, sebuah wilayah perkebunan dan pertanian yang juga merupakan daerah wisata. Selain bertani, masyarakat disini banyak yang membuka wirausaha. Produk-produk UMKM yang dihasilkan seperti makanan ringan, perabot, gula aren dan lainnya. Berdasarkan analisis kondisi nyata yang terdapat di Nagari Kamang Hilir dapat diidentifikasi permasalahan-permasalahan yang dihadapi berkaitan dengan masalah kewirausahaan yaitu, manajemen usaha, manajemen SDM dan promosi produk. Tujuan yang diharapkan tercapai dari kegiatan pengabdian ini adalah masyarakat memahami berbagai hal yang berkaitan dengan kewirausahaan, mampu meningkatkan manajemen usaha, mampu meningkatkan manajemen sumber daya manusia, dan mampu meningkatkan promosi produk dan pemasarannya bukan hanya di wilayah Kabupaten Agam saja tetapi juga bisa merambah ke berbagai daerah lain. Kegiatan dilakukan selama 3 bulan, mulai dari survei, wawancara, kegiatan di lapangan hingga membuat laporan akhir. Metode yang dilakukan dalam kegiatan pengabdian ini adalah memberikan penyuluhan atau ceramah. Penyuluhan dilakukan dengan memberikan materi yang berkaitan dengan kewirausahaan, manajemen usaha, manajemen SDM dan promosi produk.
\end{abstract}

Kata kunci: UMKM, manajemen usaha, SDM, promosi

\section{PENDAHULUAN}

Kamang Hilir merupakan salah satu desa atau nagari yang terletak di kecamatan Kamang Magek, kabupaten Agam, provinsi Sumatera Barat. Nagari ini terletak sekitar $12 \mathrm{~km}$ di sebelah timur laut Kota Bukittinggi. Luas kecamatan Kamang Magek adalah $99,6 \mathrm{~km}^{2}$, dengan jumlah penduduk sekitar 20.000 jiwa. Pada kecamatan ini terdapat 3 nagari, yaitu Nagari Kamang Hilir, Nagari Kamang Mudik dan Nagari Magek.

Pemerintah Kabupaten Agam, Sumbar, mencatat terdapat 27.856 unit usaha mikro kecil dan menegah (UMKM) yang aktif menjalankan usahanya di daerah tersebut. Puluhan Ribu UMKM ini tersebar di 16 kecamatan yang ada di Kabupaten Agam. Dari 27.856 UMKM ini, terdapat sebanyak
8.735 unit usaha yang bergerak di bidang perdagangan, seperti dagang makanan, minuman, bahan bangunan, hasil bumi dan lainnya. Sementara itu sebanyak 13.928 unit usaha bergerak di bidang industri besar dan sebanyak 5.193 unit usaha bergerak di bidang industri kecil seperti, industri makanan, minuman, sulaman, tekstil, perabot, produksi gula aren dan sebagainya (https:// sumbar.antaranews.com/berita/3 9420/kabupatenagam-miliki-27856- umkm-aktif).

Namun demikian, di tengah pertumbuhan yang cukup pesat, masih banyak terdapat kendala yang ditemui oleh pelaku UMKM dalam mengembangkan usahanya. Permasalahan terbesar dari pengembangan UMKM yakni lemahnya strategi pemasaran. Secara pasar, pelaku UMKM

$$
\text { Ekonomi, Sosial, dan Budaya }
$$


agak kesulitan untuk menjangkau luas penjualan produknya (https://sumbar.antaranews.com/berita/ 213800/permasalahan-terbesar-umkm-lemahstrategi-pemasaran).

Disamping itu permasalahan terbesar UMKM saat ini yakni kemasan produk. Kemasan produk lokal masih kurang layak untuk dijual. Makanan misalnya, dari segi bahan dan rasanya dinilai sudah bagus, cuma pengemasannya masih perlu diperbaiki. Permasalahan lain UMKM adalah masih terkendala dengan modal, penjualan, dan daya saing. Terkait penjualan, pelaku usaha masih mengandalkan cara manual. Padahal sekarang perkembangan teknologi semakin maju dan butuh cara-cara yang lebih kreatif. Begitu pula dengan daya saing produk yang masih kalah dari produk negara tetangga, seperti Malaysia dan Singapura (http://padangkita.com/punya-potensi-berkembanghal-ini-perlu-diperbaiki-umkm-sumbar/).

Permasalahan yang dihadapi oleh pengusaha UMKM makanan ringan yang ada di nagari Kamang Hilir adalah sebagai berikut :

Satu adalah usaha UMKM sulit berkembang karena kurangnya kemampuan manajemen pelaku usaha untuk mengelola usaha dengan baik.

Dua adalah kurangnya kemampuan SDM untuk dapat menginovasi produk, supaya produk bisa lebih beragam dan berbeda.

Tiga adalah kurangnya usaha promosi, karena pelaku usaha masih menjalankan bisnisnya secara manual dan konservatif.

\section{SOLUSI DAN TARGET LUARAN}

Untuk mengatasi permasalahan seperti yang telah dipaparkan di atas, ada beberapa solusi yang dapat diberikan.

Satu adalah membantu pemilik usaha/ UMKM meningkatkan kemampuan dalam mengelola manajemen usaha yaitu dengan memberikan pelatihan cara mengelola usaha yang baik. Pengetahuan tentang ini diberikan melalui ceramah yang akan diikuti oleh pelaku usaha/UMKM makanan ringan yang ada di nagari tersebut. Sehingga dengan demikian pemilik UMKM/pelaku usaha bisa lebih mampu dalam menghadapi berbagai tantangan dan hambatan dalam memajukan usahanya.

Dua adalah memberikan pengetahuan kepada pelaku usaha/UMKM mengenai pentingnya melibatkan SDM yang berkualitas dan mempunyai kompetensi dalam pengembangan UMKM. SDM yang berkualitas diharapkan mampu membuat produk yang inovatif dan lebih beragam, dan bisa menjawab segala tantangan yang dihadapi dunia usaha.

Tiga adalah memberikan pelatihan pada pelaku usaha/UMKM tentang pentingnya promosi untuk meningkatkan pemasaran dan cara meningkatkan promosi yang efektif dalam menghadapi perdagangan global.

Target luaran merupakan tujuan yang sangat diharapkan tercapai dari kegiatan pengabdian yang dilakukan ini, yaitu:

Satu adalah pelaku usaha/UMKM memahami pentingnya pengetahuan tentang manajemen usaha untuk mengelola usahanya menjadi lebih baik dan cepat berkembang.

Dua adalah pelaku usaha/UMKM memahami tentang pentingnya SDM yang berkualitas dan kapabel, sehingga kedepannya mereka mampu menghasilkan produk yang inovatif dan lebih beragam.

Tiga adalah promosi produk dapat lebih ditingkatkan dan gencar dilakukan dengan memanfaatkan teknologi internet misalnya melalui: facebook, instagram, whatsapp, dan berbagai media elektronik lainnya.

Rencana capaian untuk luaran yang ditargetkan dapat dilihat pada tabel 1 .

Tabel 1. Rencana Target Capaian Luaran

\begin{tabular}{|c|l|c|}
\hline No. & \multicolumn{1}{|c|}{ Jenis Luaran } & $\begin{array}{c}\text { Indikator } \\
\text { Capaian }\end{array}$ \\
\hline 1 & Jasa & Ada \\
\hline 2 & Metode & Ada \\
\hline 3 & $\begin{array}{l}\text { Luaran tambahan berupa } \\
\text { publikasi ilmiah di } \\
\text { jurnal/prosiding }\end{array}$ & - \\
\hline
\end{tabular}




\section{METODE PELAKSANAAN}

Pelaksanaan pengabdian kepada masyarakat ini dilaksanakan dengan kegiatan memberikan pelatihan dan penyuluhan tentang manajemen usaha, manajemen sumber daya manusia dan peningkatan promosi. Pemasaran yang tepat melalui peningkatan promosi diharapkan dapat meningkatkan penjualan dan meningkatkan pertumbuhan UMKM itu sendiri.

Objek yang dipilih sebagai sasaran yang ingin dituju dalam pelaksanaan kegiatan pengabdian kepada masyarakat ini adalah para pelaku usaha dan pemilik UMKM makanan ringan yang ada di Nagari Kamang Hilir Kec. Kamang Magek Kab. Agam, Sumatera Barat.

Dalam pengabdian ini penyampaian materi kegiatan dilakukan dengan metode ceramah/penyuluhan yang dilanjutkan dengan pelatihan dan praktik. Kegiatan tersebut digunakan dengan alat bantu multi media berupa laptop dan LCD Proyektor untuk memudahkan pemahaman peserta dan supaya kegiatan tersebut menjadi lebih menarik.

Penyampaian materi dalam kegiatan ini dilakukan dengan metode ceramah/penyuluhan, yang kemudian dilanjutkan dengan sesi tanya jawab. Pada metode ceramah ini, para peserta disatukan dalam ruangan, kemudian mereka menerima materi yang diberikan oleh nara sumber/trainer, dengan diselingi pertanyaanpertanyaan yang diajukan. Setiap peserta memperoleh materi (handout) yang disampaikan.

Adapun tahapan kegiatan dapat dijelaskan sebagai berikut:

Satu adalah persiapan kegiatan. Pada tahap persiapan ini dilakukan kegiatan seperti mengidentifikasi, menyeleksi dan pengelompokkan calon peserta kegiatan mempersiapkan tempat, sarana, narasumber/trainer dan bahan/alat pembelajaran kegiatan. Kemudian mengidentifikasi dan menyusun pola program dan training yang tepat dan berhasil guna.

Dua adalah pelaksanaan kegiatan. Pelatihan/ceramah dalam kegiatan ini dilaksanakan dengan cara memberikan pengetahuan kepada $\mathrm{UMKM} /$ pelaku usaha tentang bagaimana mengelola/manajemen usaha yang baik, dan mengelola SDM. Selanjutnya memberikan pelatihan tentang bagaimana meningkatkan promosi untuk meningkatkan pemasaran.

Tiga adalah evaluasi. Evaluasi dilakukan untuk mengkaji atau menilai pelaksanaan kegiatan dengan tujuan memperbaiki atau menyempurnakan kegiatan. Dalam hal ini, evaluasi dilakukan secara formatif, yaitu pada saat kegiatan masih berlangsung maupun secara sumatif, yaitu pada saat kegiatan pelatihan sudah berakhir.

\section{HASIL DAN PEMBAHASAN}

\section{Hasil Kegiatan}

Program Pengabdian kepada Masyarakat (PPM) ini disambut dengan sangat baik oleh masyarakat kenagarian Kamang Hilir, terutama masyarakat pemilik UMKM makanan ringan yang ada di kenagarian tersebut. Hal ini menunjukkan bahwa pengusaha UMKM memang sangat membutuhkan perhatian dari berbagai pihak. Maksud dan tujuan progam PPM yang dipaparkan oleh tim pengabdi, mereka terima dengan sangat antusias. Bahkan masyarakat pengusaha UMKM berharap semoga kegiatan yang sejenis dengan pengabdian ini selalu ada setiap tahun, sehingga para pengusaha kecil tersebut selalu mendapat perhatian dan bantuan. Masyarakat pengusaha UMKM juga menyatakan bahwa sebelumnya mereka juga sudah beberapa kali menerima kedatangan berbagai kelompok pemerhati, termasuk dari pemerintah sendiri. Di antara mereka ada juga yang memberi bantuan dan hal itu dinyatakan sangat membantu bagi pengembangan dan keberlanjutan usaha UMKM di daerah ini.

Kegiatan dalam program Pengabdian kepada Masyarakat ini dilaksanakan dengan metode pendekatan, diskusi dan pembinaan/penyuluhan. Semua metode ini telah disetujui oleh pimpinan masyarakat nagari Kamang Hilir karena bagi mereka yang terpenting adalah program apa pun yang ditawarkan dianggap baik selama dapat memberi pengaruh positif bagi kegiatan usaha UMKM di daerah ini. Hasil pelaksanaan setiap kegiatan ini dapat dijabarkan sebagai berikut:

$$
\text { Ekonomi, Sosial, dan Budaya }
$$


Satu adalah tahap diskusi. Tim pengabdian melakukan diskusi dengan pimpinan masyarakat nagari Kamang Hilir mengenai berbagai hal yang dapat dijadikan bahan masukan dalam mendukung jalannya kegiatan ini. Diskusi ini penting agar tujuan yang diinginkan dari pelaksanaan program PPM ini tercapai sesuai dengan yang diharapkan. Selama melakukan diskusi, pihak pimpinan masyarakat dengan terbuka memberikan berbagai keterangan yang diinginkan oleh tim pengabdi.

Dalam diskusi ini, pimpinan masyarakat diajak untuk menyampaikan permasalahan yang dialami oleh pengusaha UMKM di kenagarian Kamang Hilir itu sendiri. Berbagai masalah yang dihadapi oleh masyarakat UMKM, misalnya tentang masih kurangnya perhatian dari pemerintah dan dinas terkait, masalah permodalan, pemasaran produk, dan lain sebagainya, terungkap dalam diskusi ini.

Dalam diskusi ini juga dibahas langkahlangkah dan metode selanjutnya yang akan ditempuh. Untuk melaksanakan metode pembinaan dan penyuluhan, pimpinan masyarakat kenagarian Kamang Hilir bersedia mencarikan waktu dan tempat untuk menyelenggarakan kegiatan tersebut. Pimpinan masyarakat kenagarian Kamang Hilir juga ikut aktif menyosialisasikan program ini kepada masyarakat pengusaha UMKM dan bersedia mengumpulkan mereka saat dibutuhkan untuk melaksanakan program ini. Selama ini pimpinan masyarakat kenagarian Kamang Hilir merasa bahwa masyarakat pengusaha UMKM masih kurang pemahaman dalam masalah manajemen usaha dan peningkatan promosi usahanya. Sebab itu, pimpinan masyarakat kenagarian Kamang Hilir bersedia mengikuti saran dan bantuan tim pengabdi untuk membenahi masalah tersebut. Pimpinan masyarakat kenagarian Kamang Hilir meyakini bahwa masyarakat pengusaha UMKM bersedia menerima semua masukan dari tim pelaksana dan akan melaksanakannya karena penting bagi perkembangan usaha mereka.

Dua adalah tahap Pembinaan dan Penyuluhan. Metode pembinaan dan penyuluhan terhadap masyarakat pengusaha UMKM ini diberikan kepada masyarakat pengusaha UMKM agar dapat menjalankan usaha dan menghasilkan keuntungan yang sesuai dengan harapan mereka.
Tim pelaksana pengabdian memberikan ilmu pengetahuan dan informasi kepada masyarakat pengusaha UMKM mengenai manajemen usaha dan peningkatan promosi usaha dengan tujuan agar pemilik UMKM dapat menjalankan usahanya melalui manajemen yang baik dan dapat meningkatkan promosi terhadap produk mereka untuk meningkatkan volume penjualan.

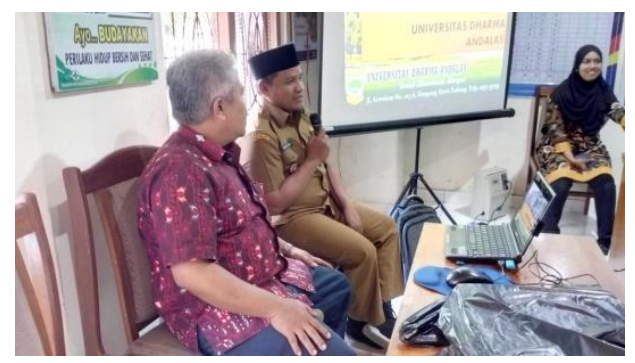

Gambar 1. Wali Nagari Kamang Hilir Sedang Memberikan Kata Sambutan

Dalam pembinaan dan penyuluhan tentang manajemen usaha, tim pengabdian memberi pembinaan dan penyuluhan kepada masyarakat pengusaha UMKM tentang berbagai aspek di dalam manajemen usaha yang harus bisa dikelola dengan baik oleh pengusaha UMKM, yaitu:

Pertama adalah manajemen keuangan. Pengusaha UMKM harus bisa membedakan antara uang pribadi dan uang usaha. Jangan mencampuradukkan antara keuangan pribadi dan bisnis. Segala transaksi harus dicatat dengan baik, uang masuk dan uang keluar. Laba yang diperoleh harus diperhatikan. Apakah meningkat atau menurun. Kalau menurun, harus segera dicari tahu faktor penyebabnya agar bisa segera diatasi.

Kedua adalah manajemen SDM. Manajemen SDM penting untuk mengetahui sejauh mana SDM bisa dimaksimalkan. Pengusaha UMKM bisa memulai dengan level pendidikan karyawan. Pendidikan disini maksudnya bukan pendidikan formal, tetapi lebih menekankan kepada pendidikan SDM dalam menjalankan sebuah bisnis. Pengusaha UMKM harus selalu bisa berinovasi agar mampu bersaing dengan sehat. SDM harus terus dilatih sehingga mereka akan lebih produktif dalam menjalankan usaha.

Ketiga adalah manajemen resiko. Dalam dunia bisnis selalu ada resiko. Pengusaha UMKM 
harus cermat menganalisa masalah dan resiko yang akan terjadi. Pengusaha UMKM harus bisa meminimalisir resiko kerugian perusahaan atau bisnis mereka tersebut. Melalui manajemen resiko pengusaha UMKM bisa memprediksi resiko dan selanjutnya akan bisa pula meminimalisir kerugian bagi bisnisnya.

Keempat adalah manajemen pemasaran. Masalah pemasaran disini bukan hanya perkara bagaimana produk bisa sampai ke tangan konsumen tetapi juga kesesuaian antara apa yang diinginkan oleh pasar dengan produk yang ditawarkan. Selain itu, iklan, sosialisasi dan lain sebagainya juga termasuk ke dalam manajemen pemasaran ini. Pemasaran yang tepat akan bisa menghemat dana, tenaga dan waktu yang dikeluarkan oleh setiap pengusaha.

Kelima adalah manajemen produksi. Ketika berbicara tentang produk, sebenarnya kita sedang berbicara tentang kualitas karena keberadaan suatu produk sangat tergantung kepada kualitas produk tersebut. Jadi pengusaha UMKM harus memastikan bahwa produk yang dihasilkan memiliki kualitas yang terbaik. Bahkan, sebaiknya bisnis UMKM memerlukan standarisasi untuk produk yang dihasilkan. Standarisasi tersebut akan meningkatkan mutu dan kualitas produk.

Keenam adalah manajemen pengembangan. Pengembangan bisa diartikan banyak hal terutama untuk mengembangkan bisnis pengusaha UMKM menjadi semakin besar dan luas. Untuk itu tentu diperlukan sistem manajemen yang tepat agar pengembangan bisa berjalan secara efektif dan efisien. Jika pengembangan usaha dilakukan dengan terburu-baru, tanpa rencana matang, maka hasil yang akan diperoleh justru bisa membuat pengusaha menjadi rugi berlipat-lipat.

Terakhir adalah manajemen pemulihan. Setiap bisnis pada waktu tertentu bisa saja stagnan, tidak berkembang bahkan macet. Jika pengusaha UMKM mengalami kondisi seperti ini, maka yang dibutuhkan adalah manajemen pemulihan. Pemulihan bisa dimulai dengan mencari masalah baik internal dan eksternal kemudian dicarikan solusinya. Setelah itu, lakukan beberapa perbaikan.

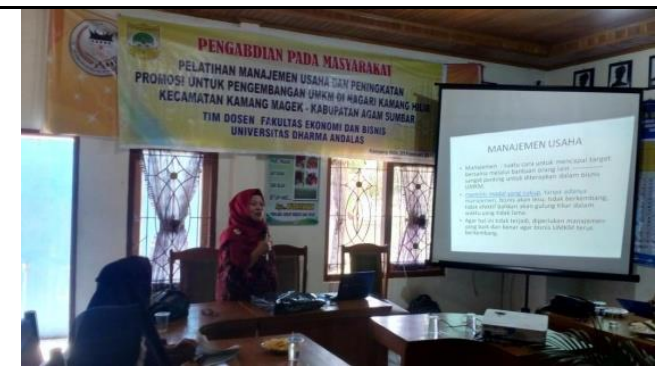

Gambar 2. Tim Pengabdian Sedang Memberikan Penyuluhan Manajemen Usaha

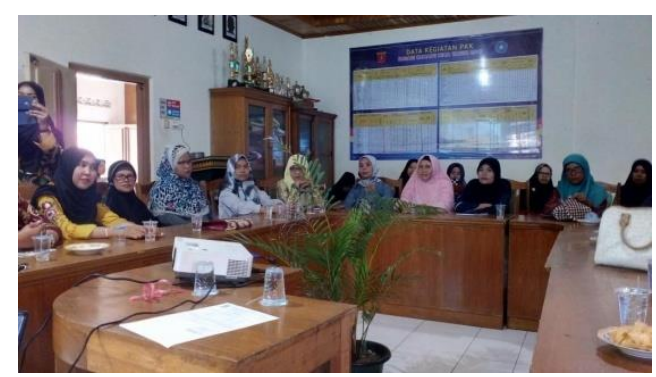

Gambar 3. Pengusaha UMKM Mendengarkan Penyuluhan dengan Antusias

Penyuluhan selanjutnya diarahkan kepada masalah peningkatan promosi. Selama ini promosi masih dilakukan dengan cara sederhana, ditambah lagi dengan lokasi usaha yang jauh dari kota dan pusat keramaian menjadi suatu kendala tersendiri untuk menarik perhatian konsumen. Tim pengabdian membina pemilik usaha untuk menggiatkan promosi produknya dengan melakukan berbagai inovasi, misalnya membuat kemasan produk yang lebih khas dan unik sehingga produk yang dihasilkan oleh UMKM menjadi berbeda dari pada produk lain yang sejenis. Bisa juga dengan memberikan nama yang unik pada produk mereka sehingga menarik perhatian konsumen. Kedua hal ini penting dilakukan untuk memberi nilai tambah pada produk agar lebih menarik, dimana konsumen merasa membeli produk "berbeda" dengan membeli produk yang sama di tempat lain.

Untuk lebih meningkatkan promosi, tim pengabdi menghimbau masyarakat pengusaha UMKM untuk sering mengikuti berbagai iven/bazar/pameran. Untuk itu pengusaha UMKM harus rajin mencari informasi dari berbagai media massa, cetak mau pun elektronik, dan bisa juga langsung mencari informasi ke kantor berbagai instansi terkait, seperti dinas perdagangan, pariwisata dan lain-lain mengenai Ekonomi, Sosial, dan Budaya

1201 
iven/bazar/pameran yang akan diadakan.

Kemudian tim pengabdian juga mengajak pengusaha UMKM untuk memanfaatkan teknologi informasi sebagai sarana peningkatan promosi usaha, yaitu melakukan penjualan secara online. Pengusaha UMKM bisa mempromosikan produknya dengan memanfaatkan berbagai media sosial, seperti facebook, instagram, whatsapp, dan lain-lain. Pemasaran online lebih memudahkan pengusaha UMKM dalam memperkenalkan produknya kepada masyarakat luas secara langsung.

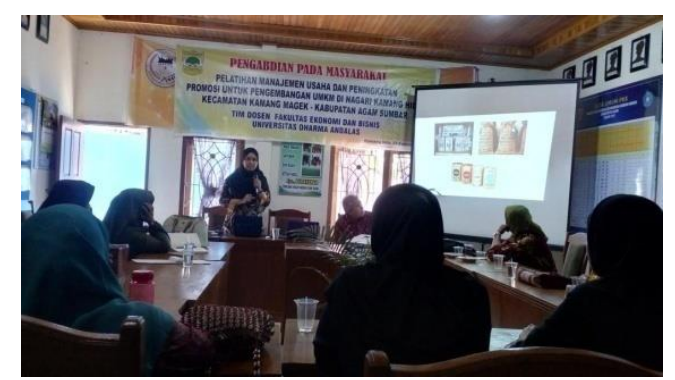

Gambar 4. Tim Pengabdian Sedang Memberikan Penyuluhan tentang Peningkatan Promosi

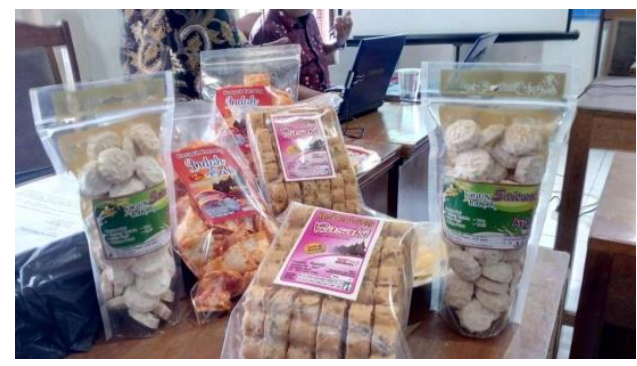

Gambar 5. Beberapa Contoh Produk UMKM di Nagari Kamang Hilir

Ceramah/penyuluhan ini dilakukan dalam suasana yang santai dan menyenangkan bagi masyarakat pengusaha UMKM, sehingga mereka tidak merasa terpaksa untuk mendengarkan penyuluhan, tidak merasa digurui apalagi diremehkan. Selama kegiatan berlangsung, terlihat bahwa para pengusaha UMKM sangat antusias untuk mendengarkan penyuluhan. Secara umum kegiatan ini dapat dikatakan berjalan dengan sukses dan lancar serta sesuai dengan harapan.

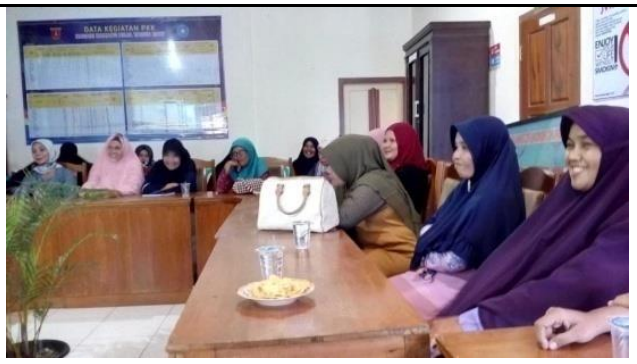

Gambar 6. Suasana Penyuluhan di Kantor Wali Nagari Kamang Hilir

Pelatihan diselenggarakan di Kantor Wali Nagari Kamang Hilir pada tanggal 25 Februari 2019 yang dihadiri oleh Wali Nagari. Materi disampaikan sendiri oleh tim pengabdian dengan peserta yang hadir adalah masyarakat pengusaha UMKM bersama dengan para pimpinan kenagarian Kamang Hilir.

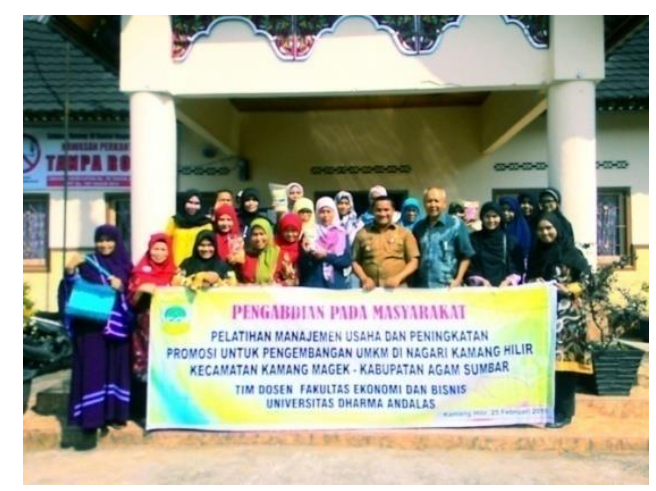

Gambar 7. Foto Bersama Tim Pengabdian dengan Pengusaha UMKM dan Wali Nagari Kamang Hilir

\section{Pembahasan}

Melalui metode pembinaan dan penyuluhan yang telah dilakukan, masyarakat pengusaha UMKM sudah mengetahui cara mengelola usaha dengan baik dan pentingnya manajemen usaha dalam menjalankan suatu bisnis. Mereka juga sudah mengetahui cara untuk meningkatkan promosi produknya sehingga diharapkan ke depannya penjualan dapat mengalami peningkatan. Masyarakat pengusaha UMKM di kenagarian Kamang Hilir akan menempuh cara meningkatkan promosi produk seperti yang disarankan tim pengabdi, seperti membuat bentuk kemasan produk yang menarik dengan nama usaha sendiri yang unik sehingga berbeda dari produk lain yang sejenis dan menarik perhatian komsumen.

$$
\text { Ekonomi, Sosial, dan Budaya }
$$


Masyarakat pengusaha UMKM di kenagarian Kamang Hilir juga berminat untuk memajang produk-produknya pada iven/bazar/pameran yang ada. Masyarakat pengusaha UMKM ini juga akan melakukan penjualan secara online, sehingga jangkauan daerah pemasaran menjadi lebih luas dan mudah didapat oleh masyarakat.

Dengan semua hal yang telah dilakukan, maka jumlah pemesanan produk pengusaha UMKM di kenagarian Kamang Hilir diharapkan menjadi lebih meningkat dari pada sebelumnya. Diharapkan ke depannya masyarakat pengusaha UMKM akan mengalami peningkatan omzet yang cukup baik. Diharapkan juga berikutnya akan terjadi pengembangan usaha dan penyerapan tenaga kerja.

Pengabdian ini juga diharapkan memberi dampak yang positif kepada masyarakat pengusaha UMKM supaya selalu termotivasi dalam berusaha, meningkatkan kreativitas dan inovasi dalam pengembangan usaha dan produknya sehingga dapat menghasilkan produk yang lebih baik, lebih berkualitas dan lebih disukai lagi oleh konsumen.

\section{KESIMPULAN DAN SARAN}

\section{Kesimpulan}

Setelah melakukan kegiatan pengabdian, kami mendapat kesimpulan bahwa secara umum masyarakat pengusaha UMKM di kenagarian Kamang Hilir sangat membutuhkan bantuan dari berbagai pihak, baik itu berupa bantuan permodalan mau pun berupa transfer ilmu pengetahuan dan teknologi (iptek), yang memudahkan mereka dalam menjalankan roda usahanya menjadi lebih baik dan berkembang sesuai harapan.

Masyarakat pengusaha UMKM di kenagarian Kamang Hilir tertarik untuk mengetahui lebih jauh tentang manajemen usaha dan cara meningkatkan promosi. Mereka mengajukan beberapa pertanyaan tentang cara mengelola usaha, mengelola usaha, dan sebagainya. Mereka juga tertarik mengetahui tempat memesan kemasan dan membuat nama perusahaan. Animo masyarakat pengusaha UMKM yang tinggi itu merupakan suatu hal yang sangat positif dan patut disambut dengan baik sebagai bekal bagi pengembangan kemampuan mereka dalam mengelola usaha dan meningkatkan promosi produknya.

Pengusaha UMKM sangat mengharapkan adanya kesinambungan dan keberlanjutan perhatian dari berbagai pihak, baik dari perguruan tinggi mau pun dari berbagai instansi terkait, agar berbagai usaha UMKM yang tumbuh di masyarakat dapat lebih berkembang dan lebih maju lagi menjadi suatu usaha yang kuat dan handal.

\section{Saran}

Mengingat besarnya animo masyarakat pengusaha UMKM di kenagarian Kamang Hilir untuk memperdalam pengetahuan mereka mengenai pengelolaan dan pengembangan sebuah usaha, disarankan hal-hal sebagai berikut :

Satu adalah supaya pemerintah lebih aktif dalam melakukan pembinaan bagi masyarakat pengusaha UMKM ini melalui pelatihan dan penyuluhan agar produk yang dihasilkan lebih sesuai dengan perkembangan zaman.

Dua adalah pemerintah lebih sering mengadakan pameran dan bazar dan aktif menyosialisasikan pameran dan bazar tersebut kepada masyarakat supaya produk UMKM lebih dikenal lagi oleh masyarakat luas.

Tiga adalah pemerintah memberikan bantuan kredit tanpa agunan bagi UMKM supaya mereka lebih berkembang.

Empat adalah peranan perguruan tinggi supaya lebih ditingkatkan dengan melakukan pembinaan dan penyuluhan dalam rangka transfer ilmu pengetahuan dan teknologi melalui kegiatan pengabdian kepada masyarakat.

Lima adalah bagi masyarakat pengusaha UMKM diharapkan untuk lebih antusias lagi dalam mengikuti berbagai kegiatan, pameran dan bazar yang diselenggarakan oleh pemerintah mau pun perguruan tinggi.

\section{UCAPAN TERIMA KASIH}

Dalam melaksanakan pengabdian kepada masyarakat ini, banyak pihak yang ikut membantu kami baik secara langsung maupun tidak langsung.

$$
\text { Ekonomi, Sosial, dan Budaya }
$$


Ungkapan terima kasih yang sebesar-besarnya penulis sampaikan kepada Bapak Prof. Dr. Deddi Prima Putra, Apt, selaku Rektor Universitas Dharma Andalas Padang, Ibu Dr. Asniati, SE, MBA, Ak, CA, CSRA, selaku Dekan Fakultas Ekonomi dan Bisnis Universitas Dharma Andalas Padang, Bapak Dr. Heru Aulia Azman, S.Sos, MM, Ph.D selaku Ketua LPPM Fakultas Ekonomi dan Bisnis Universitas Dharma Andalas Padang, rekanrekan Staf Pengajar pada Universitas Dharma Andalas, seluruh anggota tim pengabdian masayarakat yang turut membantu terlaksananya kegiatan ini, dan juga kepada seluruh anggota masyarakat Kenagarian Kamang Hilir yang telah ikut membantu terlaksananya kegiatan ini.

\section{DAFTAR REFERENSI}

https://sumbar.antaranews.com/berita/39420/kabupa ten-agam-miliki-27856-umkm-aktif

https://sumbar.antaranews.com/berita/213800/perm asalahan-terbesar-umkm-lemah-strategipemasaran

http://padangkita.com/punya-potensi-berkembanghal-ini-perlu-diperbaiki-umkm-sumbar/ 